\title{
ENVIRONMENTAL FACTORS IN THE AETIOLOGY OF GASTRIC CANCER
}

\author{
BY \\ DAVID J. B. ASHLEY, M.D., M.C.Path. \\ Consultant Pathologist, Morriston Hospital, Swansea
}

Gastric cancer is one of the commoner causes of death in the United Kingdom but its frequency varies considerably from one part of the country to another. The standardized mortality ratios (SMRs) for the counties and county boroughs of England and Wales for the year 1961 show a range of from 59 to 164 in the case of males and from 41 to 163 in the case of females (Registrar General, 1967). The present analysis follows that made in respect of lung cancer and bronchitis (Ashley, 1969) and is based on mortality and environmental data from 53 towns in which stations for the assay of air pollution had been set up.

The standardized mortality ratios were calculated for the years 1958 to 1963 from the published data of the Registrar-General (1960a, 1960b, 1962, 1963, 1964a, 1964b, 1965). The environmental parameters used were the population density (persons per acre) from the Registrar General's statistics (1964b); a social class index which comprised the proportion of the working male population who were in classes 10 (semi-skilled manual workers), 11 (unskilled manual workers), and 15 (agricultural workers) (General Register Office, 1965); the extent of atmospheric pollution by smoke and sulphur dioxide recorded at gauges set up in residential areas (Department of Scientific and Industrial Research, 1963); and a final separation into towns in which the dusty mining and textile industries were important employers of labour (Ashley, 1967, 1969).

TABLE I

CORRELATION COEFFICIENTS BETWEEN GASTRIC CANCER MORTALITY AND ENVIRONMENTAL VARIABLES FOR 53 TOWNS

\begin{tabular}{|c|c|c|c|c|}
\hline & \multicolumn{2}{|c|}{ Male } & \multicolumn{2}{|c|}{ Female } \\
\hline & $\begin{array}{l}\text { Coeffi- } \\
\text { cient }\end{array}$ & $\begin{array}{l}\text { Signifi- } \\
\text { cance }\end{array}$ & $\begin{array}{l}\text { Coeffi- } \\
\text { cient }\end{array}$ & $\begin{array}{c}\text { Signifi- } \\
\text { cance }\end{array}$ \\
\hline $\begin{array}{l}\text { Population density } \\
\text { Social status } \\
\text { Smoke } \\
\text { Sulphur dioxide }\end{array}$ & $\begin{array}{l}0 \cdot 33 \\
0 \cdot 564 \\
0.454 \\
0 \cdot 377\end{array}$ & $\begin{array}{l}5 \% \\
1 \% \\
1 \%\end{array}$ & $\begin{array}{l}0 \cdot 118 \\
0.493 \\
0 \cdot 365 \\
0.340\end{array}$ & $\begin{array}{l}\overline{1} \% \\
1 \% \\
1 \%\end{array}$ \\
\hline
\end{tabular}

Straightforward correlation coefficients between gastric cancer mortality and the four environmental variables were calculated (Table I). There was a highly significant positive correlation between each of the SMRs and the index of social status and the two atmospheric pollution parameters and a significant positive correlation between population density and the SMR for gastric cancer in men but not in women. The correlation coefficient is not a valid method of analysis for the dichotomy into coal and textile towns and the remainder. I therefore calculated the mean SMRs for the whole group of towns, for the coal and textile towns, and for the remainder (Table II). The mean SMR for gastric cancer was markedly higher in the case of the coal and textile towns than in the remaining towns for both males and females.

TABLE II

MEAN SMRS FOR GASTRIC CANCER IN COAL AND TEXTILE TOWNS

\begin{tabular}{l|c|c}
\hline & Male & Female \\
\hline All towns & 113.4 & 112.2 \\
Coal and textile towns & 128.6 & 130.8 \\
Remainder & 106.4 & 103.7 \\
\hline
\end{tabular}

The environmental parameters used are, however, themselves closely inter-related (Ashley, 1969). The analysis was completed by using the technique of multiple regression. Regression coefficients were calculated for each of the environmental variables against the mortality experience of men and women, and their significance was tested using the statistic F (Seal, 1964) (Table III). There was a positive association with the two social factors; this was highly significant in the case of males and significant at the $5 \%$ level in the case of females. There was a significant positive association with the parameter related to dusty industries. This was highly significant in the case of males and significant at the $5 \%$ level in the case of females. There was a positive association, significant at the $5 \%$ 
TABLE III REGRESSION COEFFICIENTS BETWEEN GASTRIC CANCER AND ENVIRONMENTAL VARIABLES

\begin{tabular}{|c|c|c|c|c|c|c|}
\hline & \multicolumn{3}{|c|}{ Male } & \multicolumn{3}{|c|}{ Female } \\
\hline & Coefficient & $\mathbf{P}$ & $\begin{array}{c}\text { Level of } \\
\text { Significance }\end{array}$ & Coefficient & $\mathbf{F}$ & $\begin{array}{c}\text { Level of } \\
\text { Significance }\end{array}$ \\
\hline $\begin{array}{l}\text { Population density } \\
\text { Social status } \\
\text { Coal/textile } \\
\text { Smoke } \\
\text { Sulphur dioxide }\end{array}$ & $\left.\begin{array}{l}1 \cdot 11 \\
0 \cdot 13 \\
9 \cdot 20 \\
0 \cdot 04 \\
0 \cdot 005\end{array}\right\}$ & $\begin{array}{r}12 \cdot 1 \\
14 \cdot 8 \\
5 \cdot 5 \\
5 \cdot 1\end{array}$ & $\begin{array}{l}1 \% \\
1 \% \\
5 \% \\
5 \%\end{array}$ & $\left.\begin{array}{r}0.26 \\
0.18 \\
11.46 \\
-0.05 \\
0.07\end{array}\right\}$ & $\begin{array}{l}4 \cdot 1 \\
6 \cdot 6 \\
0 \cdot 28 \\
0 \cdot 81\end{array}$ & $\begin{array}{l}5 \% \\
5 \%\end{array}$ \\
\hline
\end{tabular}

level, between the degree of atmospheric pollution and the SMR for gastric cancer in males but not in females.

\section{Discussion}

The associations brought out in this analysis present several points of interest. An association between gastric cancer and lower social class has been reported by Clemmesen and Nielsen (1951) in Denmark and by Doll (1956) in Britain. This association is confirmed by the data presented here. The small urban/rural difference noted by Doll (1956) may also be related to socio-economic factors.

The association with high levels of atmospheric pollution which was found in the case of males was unexpected. In general, carcinogens acting on the upper gastro-intestinal tract are likely to be ingested rather than inspired, but it may be suggested that contamination of food by atmospheric pollutants could occur. Alternatively, it may be postulated that, as chronic infection of the respiratory tract is commoner in men than in women, atmospheric pollutants might be trapped in the sputum, a considerable proportion of which is swallowed, and thereby affect the upper gastrointestinal tract. There is a strong positive correlation $(r=0.43 ; P<0.01)$ between the SMR for bronchitis in men and the SMR for stomach cancer; I have shown (Ashley, 1969) that air pollution is positively correlated with the SMR for bronchitis in males in the present series of towns.

The striking feature of the analysis presented here is the large and significant association of gastric cancer with the dusty mining and textile industries. The regression coefficients, 9.20 in the case of males and 11.46 in the case of females, were both statistically significant. Stocks (1961) made a detailed analysis of mortality from gastric cancer in the northern part of Wales and found a higher mortality among miners and farm workers than among other workers. The data presented here confirm this finding. In addition I analysed the SMRs for gastric cancer for 1961 published by the Registrar-General (1967). The mean SMR
TABLE IV

MEAN SMRS FOR 1961 FOR GASTRIC CANCER: COUNTIES OF ENGLAND AND WALES

\begin{tabular}{l|r|r}
\hline & Male & Female \\
\hline England and Wales & 97 & 100 \\
All counties & 112 & 119 \\
Coal and textile & & \\
England alone & 88 & 91 \\
All counties & 104 & 114 \\
Coal and textile & &
\end{tabular}

for the 62 counties was 97 in the case of males and 100 in the case of females; the mean SMR for the $\stackrel{5}{\rightarrow}$ 15 counties in which the coal and textile industrie $\vec{\theta}$ were prominent was 112 in the case of males and 8 119 in the case of females (Table IV). There is 8 higher mortality from gastric cancer in Wales than in England, probably because of the genetic constitution of the Welsh people (Ashley and Davies, 1966). The calculations were therefore repeated excluding the 13 Welsh counties; the results were similar again; mortality in the mining and textile counties was higher than in the remainder of the country.

Again the mechanism of the association is obscure. I have shown (Ashley, 1969) that there is a lower frequency of lung cancer in the mining and textile towns and a higher frequency of bronchitis. Respiratory disease, attributable to the inhalation of dust, is a well-known hazard of these dusty occupations and it is possible that, as in the case of atmospheric pollution, carcinogenic substances may be inhaled, trapped in the mucus of the bronchial tree, and then swallowed with the sputum. Alternatively, in these areas there may be direct contamination of food by particles in the atmosphere. More detailed study of this association is clearly needed.

\section{SUMmaRY}

The relationship between mortality from gastric cancer in men and women and a number of environmental variables has been analysed by the method of multiple regression. 
A positive association with the general social factors, population density, and social class has been confirmed.

A positive association with atmospheric pollution has been found in men but not in women.

A positive association with the dusty coal and textile industries has been found.

It is suggested that the mechanism of the association with the last two environmental factors may be related to the inhalation of carcinogenic substances followed by swallowing of sputum. An alternative suggestion is that food may be contaminated before ingestion by carcinogens in the atmosphere or in dust.

This work was carried out with a research grant from the Welsh Hospital Board.

I am indebted to the manager and staff of the Computer Centre of the Welsh Hospital Board for their ready help with the computation.

\section{REFERENCES}

Ashley, D. J. B. (1967). The distribution of lung cancer and bronchitis in England and Wales. Brit. J. Cancer, 21, 243.

- (1969). Environmental factors in the aetiology of lung cancer and bronchitis. Brit. J. prev. soc. Med., In press.

- and DAvIES, H. D. (1966). Gastric cancer in Wales. Gut, 7, 542.

Clemmesen, J., and Nielsen, A. (1951). The social distribution of cancer in Copenhagen, 1943-1947. Brit. J. Cancer, 5, 159.
Department of Scientific and Industrial Research. (1963). The investigation of atmospheric pollution. Tables of observations for the year ended March 1963.

Doll, R. (1956). Environmental factors in the aetiology of cancer of the stomach. Gastroenterologia (Basel), 86, 320.

General Register Office (1965). Census 1961. England and Wales. Occupation, Industry, Socio-Economic Groups. H.M.S.O., London.

Registrar-General (1956). Census 1951. England and Wales. Occupational Tables. H.M.S.O., London. (1960a). Statistical Review of England and Wales for the year 1958. Part I. Tables, Medical. H.M.S.O., London.

(1960b). Ibid., 1959.

(1962). Ibid., 1960.

(1963). Ibid., 1961.

(1964a). Ibid., 1962.

(1964b). Census, 1961. England and Wales. Age, Marital Condition and General Tables. H.M.S.O., London.

(1965). Statistical Reviêw of England and Wales for the year 1963. Part I. Tables, Medical. H.M.S.O., London.

(1967). Decennial Supplement England and Wales 1961. Area Mortality Tables.

SeAL, H. L. (1964). Multivariate Statistical Analysis for Biologists. Methuen, London.

STocks, P. (1961). A study of cancer mortality in farming, quarrying, mining and other occupations in North Wales and Cheshire. Brit. J. Cancer, 15, 701. 